\title{
İç ortamlarda sıcaklık ve bağıl nem parametrelerinin sosyo-ekonomik yapı ile ilişkisi
}

\author{
Nadir ÍLTEN ${ }^{1}$, Ayşe Tülay SELİCí $\dot{2}^{2}$ İsmail CANER ${ }^{1, *}$ \\ ${ }^{1}$ Balıkesir Üniversitesi Mühendislik Fakültesi, Makina Mühendisliği, Çağlş Kampüsü, Balıkesir. \\ ${ }^{2}$ Balıkesir Büyükşehir Belediyesi, Balıkesir \\ Geliş Tarihi (Recived Date): 20.04.2017 \\ Kabul Tarihi (Accepted Date): 21.09.2017
}

\section{Özet}

Insanlar, zamanlarının yaklaşık \%90'ını iç ortamlarda geçirirler. Bu nedenle, iç ortamların havası, insanların sağlıklı ve rahat edebilecekleri şekilde olmalıdır. Sıcaklık ve nem gibi değerler, iç ortamların isıl konfor parametrelerini oluşturur. Insanların çoğu, 20-25.5 ${ }^{0} \mathrm{C}$ sicaklık ve \% $30-60$ bağll nem aralı̆̆ında kendilerini rahat hissederler. Bu çalışmada; Balıkesir il merkezi sosyo-ekonomik yapı olarak 3 bölgeye ayrılmıştır. Bu bölgelerde, nüfus dağllımına bağlı olarak toplam 29 evin mutfağında klş aylarında sicaklık ve bă̆ll nem değerleri ölçülmüştür. Ölçüm değerlerinin, bölgelerle iliş̧kisi istatistiksel analizlerle incelenmiştir.

Anahtar kelimeler: Isıl konfor, sosyo-ekonomik yapı, sıcaklık, bağıl nem.

\section{The relation between indoor temperature and relative humidity parameters with socio-economic structure}

\begin{abstract}
People spend about $90 \%$ of their time indoors. Therefore, the air of the internal environment must provide healthy and comfortable conditions. Values such as temperature and humidity constitute the thermal comfort parameters of the internal environment. Most people feel comfortable between 20-25.5 ${ }^{\circ} \mathrm{C}$ and 30-60 \% temperature and humidity ranges, respectively. In this study, the central province of Ballkesir is divided into 3 zones in terms of socio-economic structure. In these regions, temperature and relative humidity levels of 29 houses during the winter were measured
\end{abstract}

Nadir İLTEN, nilten@ balikesir.edu.tr, http://orcid.org/0000-0003-4009-5078

Ayşe Tülay SELİCI, tulay.selici@balikesir.bel.tr, http://orcid.org/0000-0001-7795-7378

* İsmail CANER, ismail@balikesir.edu.tr, http://orcid.org/0000-0003-1232-649X 
depending on the population. The relationship of the regional measured values statistically investigated.

Keywords: Thermal comfort, socio-economic structure, temperature, relative humidity.

\section{Giriş}

Dünya kalkınma ajanslarına göre gelişmiş ülkelerde 2030 yılına kadar, nüfusun \%85'inin şehir merkezlerinde toplanacağı belirtilmektedir [1]. Nüfustaki bu artış, özellikle şehir merkezlerindeki bina yoğunluğunda artışa neden olacak bu durum da iklimlendirme sistemleri kullanılarak şartlandırılmış mekanlarda yaşayan insan sayısını arttıracaktır. Bu nedenle zamanlarının \%90’ınını kapalı mekanlarda geçiren insanlar için konfor şartları daha da önemli hale gelecektir [1]. Konforlu bir ortam, kişilerin performanslarını, memnuniyet düzeylerini ve sağlık durumlarını etkilemektedir [2]. İnsanların çalışma durumlarına bakılmaksızın bulundukları ortamlarda konforlu hissetmeleri oldukça önemlidir [3].

İç hava kalitesi, iç ortam havasının temizliği ile ilgili olup, insanın rahatlı̆̆ını ve sağlığını etkileyen ısıl olmayan tüm noktaları kapsar [4]. İnsanların içinde bulunduğu havayı farklı algılaması ve farklı beklentileri sebebiyle, iç hava kalitesi için kesin sınırlar çizmek veya tanımlamak zordur. Bundan dolayı, "kabul edilebilir iç hava kalitesi" terimi ortaya çıkmıştır. ASHRAE 62-1989 ve 2001 Standardında, kabul edilebilir iç hava kalitesi " içinde, bilinen kirleticilerin, yetkili kuruluşlar tarafından belirlenmiş zararlı konsantrasyon seviyelerinde bulunmadığı ve bu hava içinde bulunan insanların \%80 veya daha üzerindeki oranın havanın kalitesiyle ilgili herhangi bir memnuniyetsizlik hissetmediği havadır" olarak tanımlanmıştır $[4,5]$.

İç ortam hava kalitesi ile ilgili yapılan çalışmalarda "Kapalı Bina Sendromu" SBS (Hasta Bina Sendromu) ve BRI (Bina Bağlantılı Hastalıklar) olarak adlandırılan sağlık problemleri tanımlanmaktadır $[6,7]$.

İç ortam sıcaklığı, ssıl konfor şartlarının en önemli parametrelerinden birisidir. Yaz/kış mevsimlerine göre, insanların kendilerini rahat hissedebilecekleri bir değerde olmalıdır. Merkezi 1sıtma tesisat projelerinde, konutlarda oturma odası için iç hava sıcaklığı $22{ }^{\circ} \mathrm{C}$, banyolar için $26^{\circ} \mathrm{C}$ alınmaktadır. Büro hacimleri için iç hava sıcaklığının $20^{\circ} \mathrm{C}$ olacağı kabul edilmektedir" [8].

Yunanistan'da bulunan ilkokulların ve kreşlerin 1sıl konfor açısından değerlendirilmesinde, ilkokullarda bulunan öğrenci sayısının kreşlerden daha fazla olması sebebiyle, ilkokulların kreşlerden daha sıcak olduğu belirlenmiştir[9].

Isıl konforu etkileyen diğer bir faktör de nemdir. İç ortamın nemi, genelde bağıl nem (BN) ile ifade edilip, iç ortam bağıl nemi $\% 30$ ile \%70 arasında önerilmektedir [6, 10, 11]. İç ortamın sıcaklık ve bağıl nem değerlerinin birlikte düşünülmesi gerekmektedir. Sıcaklık ve bağıl neme göre konfor bölgeleri, yaz ve kış durumları için belirlenir [10].

Evlerin içinde meydana gelen buharlaşma, dış ortamdan daha fazladır. Oluşan buhar, soğuk hava ile karşılaşınca yoğunlaşır ve bu durum duvarların tahrip olmasına sebep olur [12]. 
Shaharon ve Jalaludin Malezya'da yaptıkları çalışmada düşük enerjili ofis binalarında, çalışanların bulunduğu ortam kalitesi ve konforunu tespit etmeye çalışmışlardır. Düşük enerjili binaların ortaya çıkmasından sonra 1sıl konfor koşullarının sağlanması, kullanıcıların rahatsız olduğu durumların önlenmesi ve kötü koşulların kullanıcı performansları üzerindeki olumsuz etkileri nedeniyle konfor standartlarında revizyon gerektiğini söylenmişlerdir. Yaptıkları ölçüm ve uyguladıkları anketler ile 1sıl konfor sicaklığının 21.6-23.6oC ve nem oranının \%42-\%54 arasında olduğunu ortaya koymuşlar ve bu değerlerin ISO 7730 ve ASHRAE 55 standartlarına uygun olduğunu göstermişlerdir [13].

Dünyanın birçok ülkesinde, iç hava kalitesiyle ile ilgili izin verilebilen maksimum sınırları belirleyen standartlar mevcuttur. Tablo 1 'de iç ortam sıcaklık ve nem değerleri ile ilgili değişik ülkelerin standartlarına ait sınır değerler verilmiştir.

Tablo 1. Bağıl Nem, Sıcaklık İle İlgili Standartlarda Önerilen Sınır Değerler

\begin{tabular}{|l|l|l|}
\hline & Bağ 1 l Nem $(\%)$ & Sicakl1k $\left({ }^{\circ} \mathrm{C}\right)$ \\
\hline ABD ASHRAE-62 [5] & $\% 30-60$ & $20-25,5^{\circ} \mathrm{C}$ \\
\hline Almanya- DIN 15251 [14] & $\% 30-70$ & $20-26{ }^{\circ} \mathrm{C}$ \\
\hline Hong Kong- HKGCC [15] & $\% 40-70$ & $20-25,5^{\circ} \mathrm{C}$ \\
\hline
\end{tabular}

\section{Yöntem}

Balıkesir İlinin büyük bir kısmı Güney Marmara Bölgesi'nde yer almaktadır. Balıkesir ilinin merkez (Altıeylül-Karesi) nüfusu 2016 yılı nüfus sayımı sonuçlarına göre yaklaşık 350000'dir [16]. Balıkesir çevresi kış dönemi kuzeyden gelen ve çok soğuk hava kütleleri ile Akdeniz üzerinden gelen nispeten 1lık etki yapan hava kütlelerinin etkisi altındadir.

Kış döneminde etkili olan yüksek basınç sistemleri yağış oluşumunu azaltır ve hava kirliliğinin daha yoğun yaşanmasına sebep olur [17]. Balıkesir'de y1llık ortalama sicaklık $14.5{ }^{\circ} \mathrm{C}$ 'dir. Ekim, Kasım, Aralık, Ocak, Şubat, Mart aylarındaki ortalama sicaklık $8.97{ }^{\circ} \mathrm{C}$ civarındadır.

Balıkesir ili genelinde kış döneminde etkili olan sis olayı aynı zamanda nem oranının \%95-100 civarına ulaşabildiğini de göstermektedir. Kış dönemindeki yüksek basınç, aşırı enerji kaybı, düşük sıcaklık nedeni ile fazla yakıt tüketimi ve bunların beraberinde görülen sis olayı hava kirliliğinin yaşanmasına sebep olmaktadır [18]. Kentin çanak şeklindeki yapı, kış aylarında hakim rüzgarların azalması, yüksek basınç ve hava sıcaklığının düşmesi hava kirliliğini arttırmaktadır [19].

Balıkesir İl Merkezinde evlerde sıcaklık ve bağıl nem gibi 1sıl konfor parametrelerinin sosyo-ekonomik özelliklere göre belirlenmesi amacıyla 168 adet (515 kişi) anket uygulanmış ve anket sonuçları tüm Balıkesir geneline yayılarak hesaplamalar yapılmıştır. Anket; evde yaşayan kişi sayısı, gelir durumu, 1sınma, pişirme, su ısıtma için kullanılan yakıt, enerji tüketimi ve tutarını içeren sorular yöneltilmiştir. 


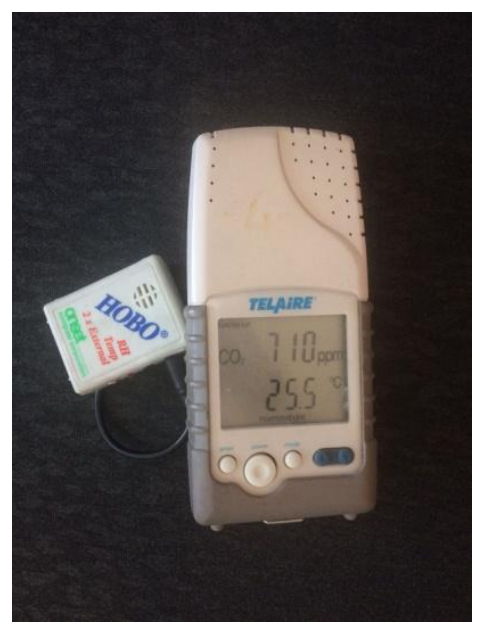

Şekil 1. Telaire $7001 \mathrm{CO}_{2} /$ Temperature Monitor ve Hobo Datalogger

Ankette Balıkesir 3 bölgeye ayrılmıştır:

1. Bölgede toplam 11 mahalle, 62.661 kişi,

2. Bölgede toplam 24 mahalle, 120.239 kişi,

3. Bölgede toplam 5 mahalle, 58.501 kişi yaşadığı 2008 yılı verilerine göre belirlenmiştir. Sosyo-ekonomik farklılıklara göre 3 bölgeye ayrılan Balıkesir'de 1.Bölge ekonomik olarak "düşük", 2. Bölge "orta", 3. bölge "yüksek" sosyo ekonomik düzeye sahip olduğu tespiti yapılmıştır. . Toplam anket sayısı mahallelerdeki nüfuslara oranlanarak belirlenmiştir (Tablo 2).

Tablo 2. Bölgelere Göre İç Hava Kalitesine Etki Eden Durumlar [20]

\begin{tabular}{lccc}
\hline & 1. Bölge & 2. Bölge & 3. Bölge \\
\hline Havalandırma Süresi (saat/gün) & $1-2$ & 1 & 1 \\
Oran (\%) & 32 & 46 & 42.9 \\
\hline Fan Kullanım Oranı (\%) & 81.4 & 80.3 & 81.4 \\
\hline Klima Kullanımı Oran (\%) & 4.7 & 11.8 & 24.5 \\
\hline Pencere İzolasyonu Oran (\%) & $<76$ & $<76$ & $<76$ \\
\hline Duvar İzolasyonu Oran (\%) & 14 & 32.9 & 36.7 \\
\hline Çat1 İzolasyonu Oran (\%) & 11.6 & 39.5 & 46.9 \\
\hline Odalarda Halı Kaplama Oran (\%) & 30.2 & 32.9 & 22.4 \\
\hline Mutfak Durumu (Ayr1/Bileşik) Oran (\%) & Ayrık (92) & Ayrık (92) & Ayrık (92) \\
\hline Sigara Kullanım Oranı (\%) & 11.6 & 22.4 & 40.8 \\
\hline
\end{tabular}

Sıcaklık ve nem değerleri, 3 bölgede toplam 29 evin mutfaklarında eş zamanlı olarak kış sezonu için ölçülmüştür. Ölçümler, 03 Ocak 2010-05 Mart 2010 tarih aralıklarında yapılmıştır. Şekil 2'de verilen harita üzerinde ölçüm yerleri işaretlenmiştir.

Sicaklık ve nem değerlerinin belirlenmesinde; "NDIR-Non Dispersive İnfrared with Automatic Basaline Correction"-Kızılötesi (NDIR) Işınlarla Otomatik Ölçüm Yöntemimetoduyla çalışan Telaire $7001 \mathrm{CO}_{2} /$ Temperature Monitor (Şekil 1) kullanılmıştır. Cihaz tarafından örnekleme süresince, yaklaşık 4 dakikalık aralıklarla toplanan veriler, veri depolayıcısına aktarılmıştır. Bu veriler daha sonra HOBO ware (version 2.1.1_18) yazılımı kullanılarak analiz edilmiştir. Bu cihazlar, evlerin mutfaklarına ve yaklaşık 1,31,5 m yüksekliğe yerleştirilmiştir. Balkon kapı ve camından uzak, ocak tipi yakma 
sistemlerine $1 \mathrm{~m}$ mesafeye monte edilmiştir. Ev halkına ölçümü doğrudan etkileyebilecek faaliyetler konusunda bilgileri verilerek belirlenen bir ölçüm prosedürüne uymaları istenmiştir [20].

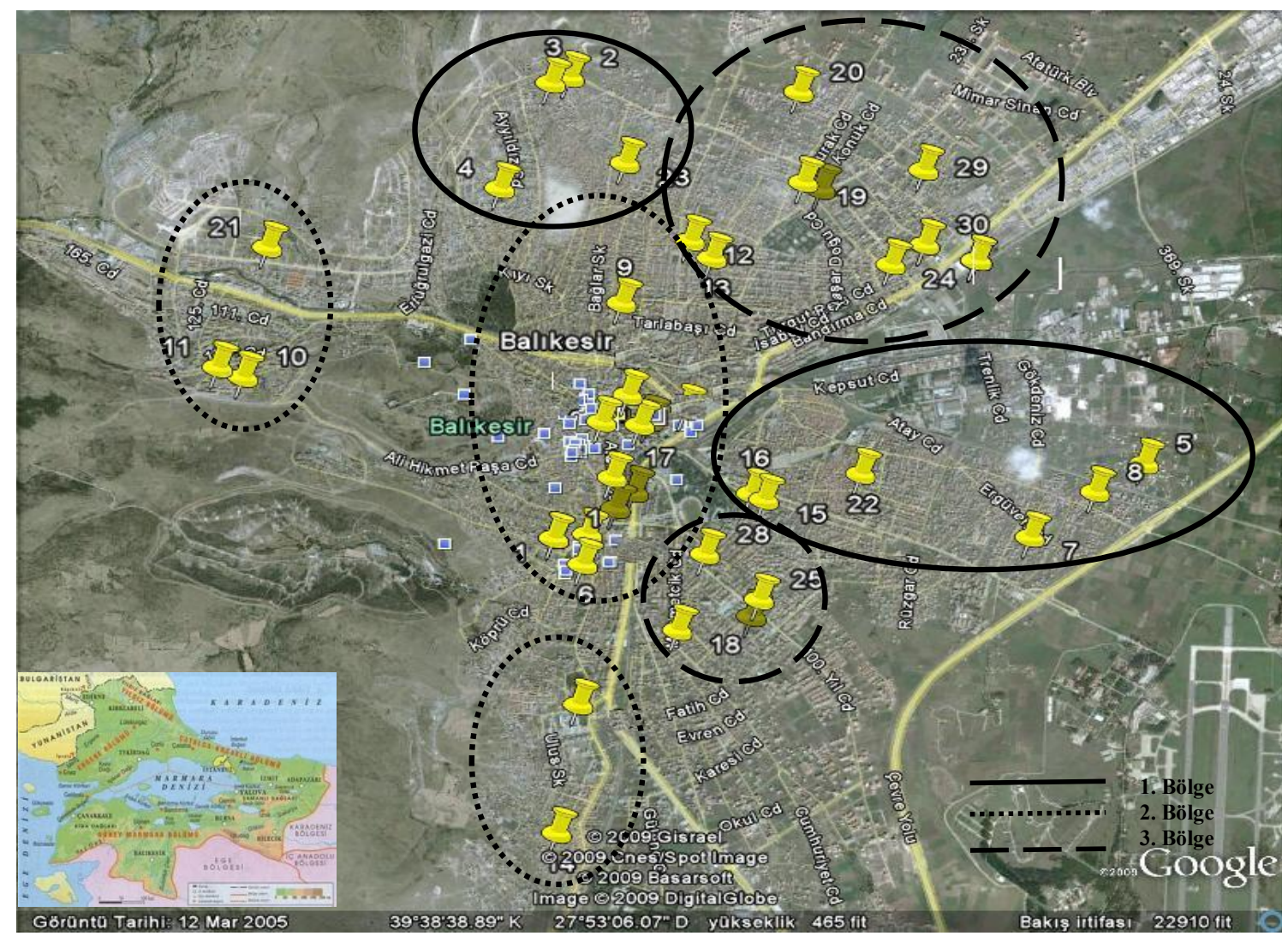

Şekil 2. Balıkesir (Merkez) Haritası ve Ölçüm Yerleri

\section{Sonuçlar}

Kış aylarında 29 adet evde ölçümü yapılan sıcaklık ve bağıl nem ölçümlerinin günlük ortalama değerleri Şekil 2 ve 3 'te verilmiştir. İç ortam sıcaklarının genellikle ASHRAE62 tarafından önerilen sınırlar arasında kalmadığı görülmektedir (Şekil 3). İç ortamda ölçülen bağıl nem değerlerinin büyük bir kısmının ASHRAE-62 tarafından önerilen (\%30-\%60) sınır değerler arasında kaldığı tespit edilmiştir (Şekil 4).

Kış aylarında iç ortamlarda ölçülen sıcaklık değerlerinin bölgelere göre günlük ortalaması; 1 . bölgede $11.53 \pm 5.22^{\circ} \mathrm{C}, 2$. bölgede $19.06 \pm 4.79{ }^{\circ} \mathrm{C}, 3$. bölgede ise 20.33 $\pm 2.49^{\circ} \mathrm{C}$ olarak bulunmuştur (Tablo 3 ).

Günlük ortalama bağıl nem değerlerinin bölgelere değişimi ise, 1. bölgede \% $64.05 \pm$ $10.30,2$. bölgede $\% 50.52 \pm 10.71,3$. bölgede $\% 46.94 \pm 9.52$ olarak bulunmuştur (Tablo 4). 


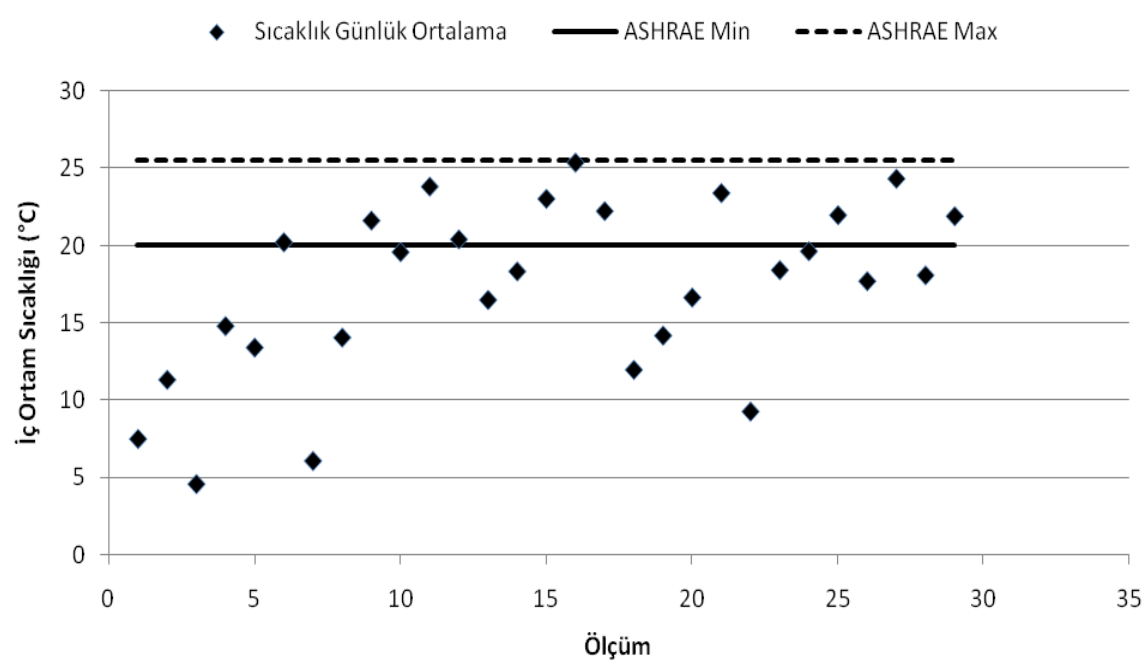

Şekil 3. Konutlarda İç Ortam Sıcaklığının Değişimi

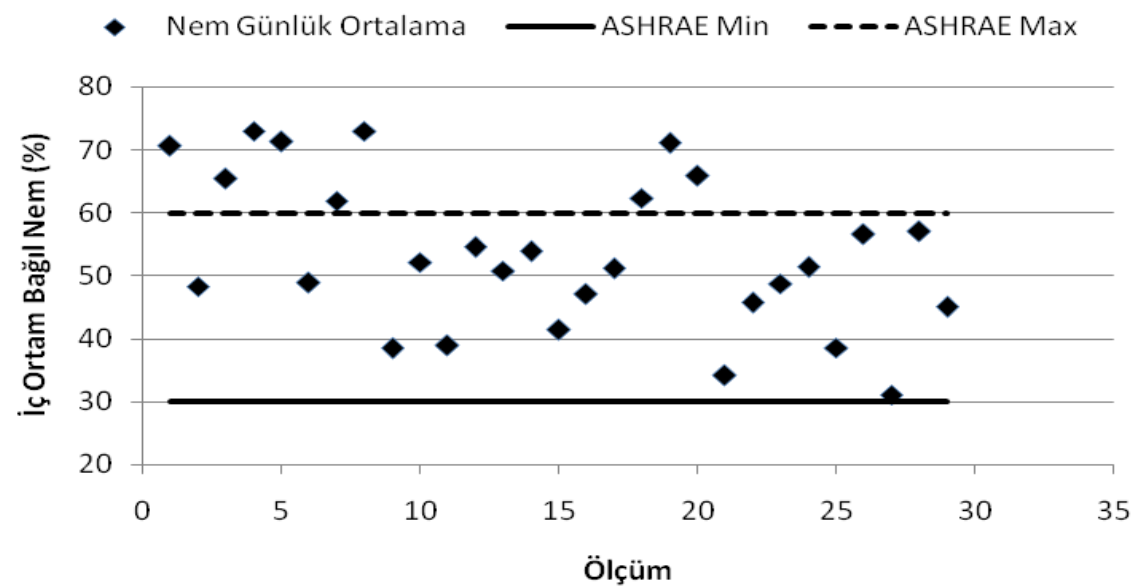

Şekil 4. İç Ortam Bağıl Nemin Değişimi

Tablo 3. Evlerin Günlük Sıcaklık Ölçümlerine Ait İstatistiksel Değerler

\begin{tabular}{|l|c|c|c|c|}
\hline & Ortalama & Standart Sapma & Maksimum & Minimum \\
\hline 1.Bölge & 11.53 & 5.22 & 20.25 & 4.62 \\
\hline 2.Bölge & 19.06 & 4.79 & 25.41 & 9.30 \\
\hline 3.Bölge & 20.33 & 2.49 & 24.37 & 17.74 \\
\hline
\end{tabular}

Tablo 4. Evlerin Günlük Mutlak Nem Ölçümlerine Ait İstatistiksel Değerler

\begin{tabular}{|l|c|c|c|c|}
\hline & Ortalama & Standart Sapma & Maksimum & Minimum \\
\hline 1.Bölge & 64.05 & 10.30 & 73.04 & 48.31 \\
\hline 2.Bölge & 50.52 & 10.71 & 71.04 & 34.14 \\
\hline 3.Bölge & 46.94 & 9.52 & 57.08 & 31.11 \\
\hline
\end{tabular}

İç ortamda evlerde ölçümü yapılan sıcaklık ve bağıl nem değerlerinin bölgelere göre değişimi Şekil 5'te gösterilmiştir. 
Sosyo-ekonomik düzeye göre belirlenen üç bölgeye ait, iç ortam 1sıl parametrelerinin değişip değişmediği tespit etmek için Anova testi gerçekleştirilerek istatistiksel olarak anlamlılıklar tespit edilmeye çalışılmıştır. Gruplar arasındaki farklılıklar Tukey testi ile belirlenmiş ve sonuçlar Tablo 5'te verilmiştir.

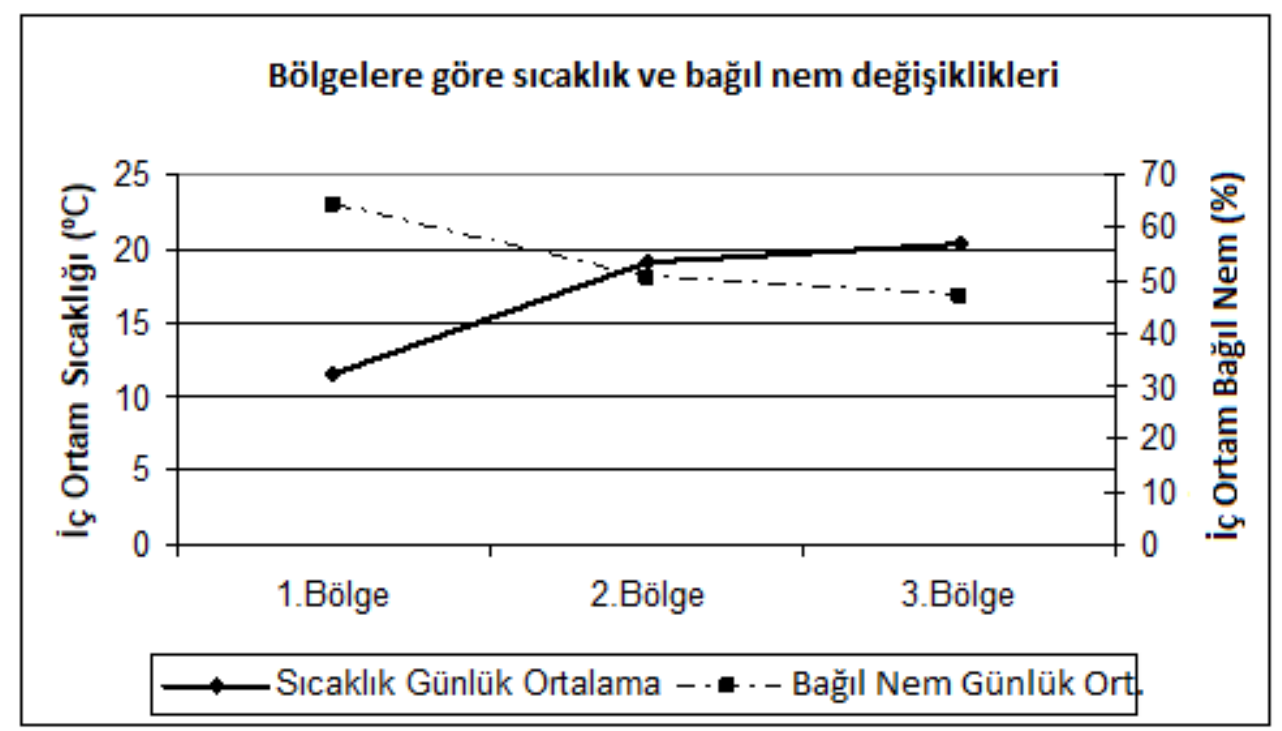

Şekil 5. İç ortam sıcaklık ve bağıl nem değerlerinin bölgelere göre değişimi

Tablo 5. İç Ortam Sıcaklık ve Nem Değerlerinin Bölgesel Farklılıkları (Anova)

\begin{tabular}{|l|l|l|r|r|c|}
\hline \multirow{2}{*}{ Bağımsız Değişken } & $(\mathrm{I})$ & \multicolumn{1}{|c|}{$(\mathrm{J})$} & $\begin{array}{c}\text { Ortalamalar } \\
\text { Fark1 (I-J) }\end{array}$ & $\begin{array}{c}\text { Std. } \\
\text { Hata }\end{array}$ & \multicolumn{1}{c|}{$\mathrm{p}$} \\
\hline Sicaklık & Düşük & Orta & -8.84 & 0.42 & 0.000 \\
& & Yüksek & -7.25 & 0.41 & 0.000 \\
\cline { 2 - 6 } & Orta & Düşük & 8.84 & 0.42 & 0.000 \\
& & Yüksek & 1.59 & 0.39 & 0.000 \\
\cline { 2 - 6 } & Yüksek & Düşük & 7.25 & 0.41 & 0.000 \\
& & Orta & -1.59 & 0.39 & 0.000 \\
\hline \multirow{3}{*}{ Nem } & Düşük & Orta & 15.07 & 0.99 & 0.000 \\
& & Yüksek & 14.53 & 0.97 & 0.000 \\
\cline { 2 - 6 } & Orta & Düşük & -15.07 & 0.99 & 0.000 \\
& & Yüksek & -0.54 & 0.91 & 0.822 \\
\cline { 2 - 6 } & Yüksek & Düşük & -14.53 & 0.97 & 0.000 \\
& & Orta & 0.54 & 0.91 & 0.822 \\
\hline
\end{tabular}

Kış aylarında iç ortamlarda ölçümü yapılan sıcaklıkların bölgelere göre değerlendirilmesinde, her üç bölgede istatistiksel olarak birbirinden anlamlı farklılıklar görülmüştür $(\mathrm{p}<0.05)$. İç ortam sıcaklık değerleri arasındaki bölgesel farklılıklar; düşük sosyo-ekonomik düzeye sahip evlerin sıcaklığı orta düzeydeki evlerden $8.84{ }^{\circ} \mathrm{C}$, yüksek düzeydeki evlerden ise $7.25^{\circ} \mathrm{C}$ daha az bulunmuştur. Kış aylarında iç ortamlardaki sıcaklıklar, gelir düzeyi düşük bölgelerde daha düşük tespit edilmiştir. 
Kış aylarında ölçümü yapılan bağıl nem değerleri bölgelere göre; düşük gelir düzeyi ile orta ve yüksek düzeydeki bölgeler arasında anlamlı farklılıklar görülürken, orta ve yüksek gelir düzeydeki bölgeler arasında anlamlı farklılık görülmemiştir $(\mathrm{p}<0.05)$. Bu farklılıklar (I-J) düşük gelir düzeyli evlerde, orta ve yüksek gelir düzeyli evlere göre sırasıyla; \%15.07 ve \% 14.53 daha yüksek bulunmuştur.

\section{Tartışma}

Balıkesir İl Merkezinde 29 adet evde, kış aylarında sıcaklık ve bağıl nem değerleri ölçümleri yapılmıştır. İç ortamda sıcaklık değerlerinin büyük bir kısmı ASHRAE-62 tarafından kabul edilebilir ısıl konfor sınırları içinde kalmazken, bağıl nem değerlerinin ASHRAE-62 tarafından önerilen sınır değerler arasında kaldığ 1 belirlenmiştir. İç ortam sıcaklık ve bağıl nemin gelir düzeyi ile olan ilişkisi Şekil 6'da gösterilmiştir. Gelir düzeyi artarken iç ortam sıcaklıklarının arttığı, bağıl nemin düştüğü belirlenmiştir. Gelir seviyesi düşük yerlerde, kış aylarında ısınma için genellikle soba kullanıldığından ve mutfakların ısıtılmadığından dolayı, sıcaklıklar düşük bulunmuştur.

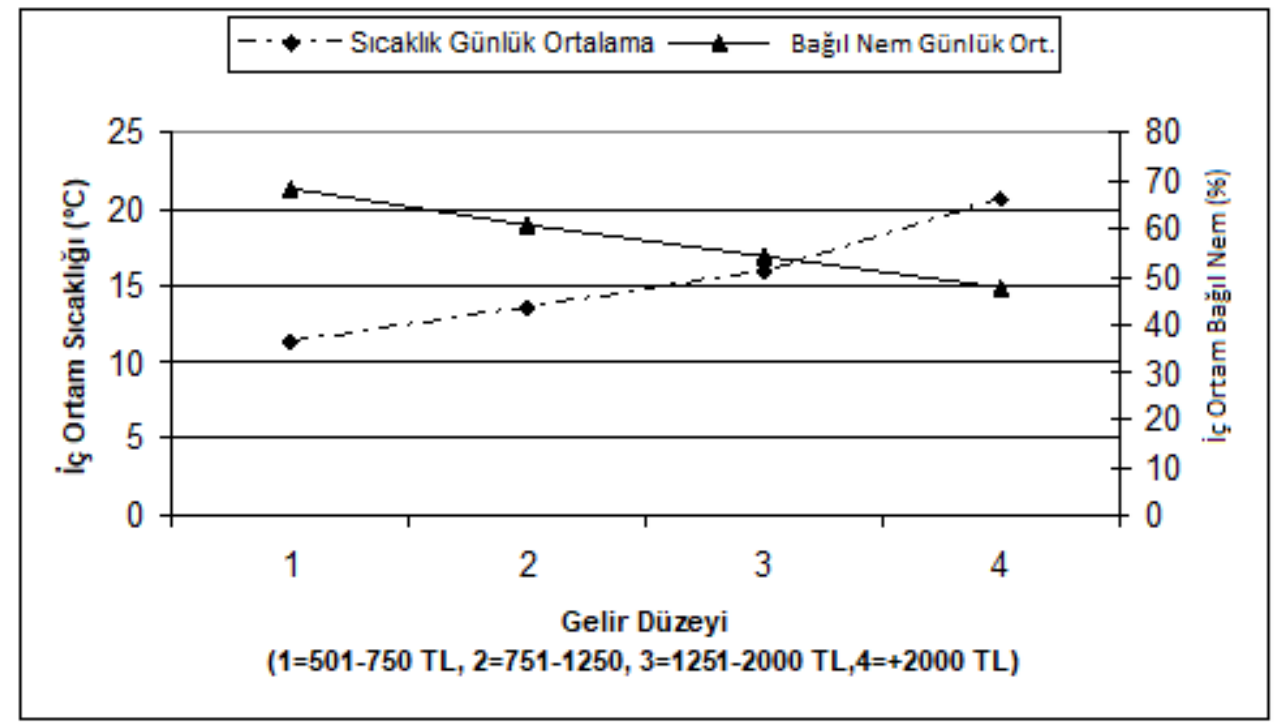

Şekil 6. İç Ortam Sıcaklığı ve Bağıl Nemin Gelir Düzeyi ile İlişkisi

Bu çalışmada, kış aylarında iç ortam sıcaklık ve bağıl nem değerleri ölçülmüş, sosyoekonomik yapıya göre değerlendirilmiştir. Gelir seviyesi arttıkça konforun yükseldiği görülmektedir. Konfor parametrelerinin yapılarda sağlanabilmesi için, gelişmiş yakma sistemleri ve izolasyon gereklidir. Isıl konfor parametrelerinin önerilen sınır değerler arasında sağlanabilmesi için yapılardaki izolasyonun teşvik edilmesi gerekmektedir. Bunun yanı sıra kış aylarındaki kötü hava koşullarının ve yemek pişirme esnasında yetersiz havalandırmanın $\mathrm{CO}_{2}$ konsantrasyonunu arttırdığı görülmüştür. Yaz ayları için binalarda bu değerler standartta belirtilen değerlerin altında kalırken, kış ayları için bu değere yakın veya yüksek olduğu belirlenmiştir. Ayrıca Kış aylarında meteorolojik faktörler nedeniyle hava kirliliğinin daha fazla hissedildiği Balıkesir İl Merkezinde yakma ile ilgili denetimlerin attırılması gerekmektedir. Kentin gelişme alanları belirlenirken hakim rüzgar yönleri dikkate alınmalıdır [20]. 


\section{Teșekkür}

$\mathrm{Bu}$ çalışma, 108Y166 No'lu ÇAYDAG TÜBİTAK 1001 Projesi tarafindan desteklenmiştir. TÜBİTAK'a destekleri için teşekkür ederiz.

\section{Kaynaklar}

[1] Ricardo Forgiarini Rupp, Natalia Giraldo Vásquez, Roberto Lamberts, A review of human thermal comfort in the built environment, Energy and Buildings, 105 178-205, (2015).

[2] Rina Maiti, PMV model is insufficient to capture subjective thermal response from Indians, International Journal of Industrial Ergonomics, 44 349-361, (2014).

[3] Niklas Fransson, Daniel Vastfjall, Jennie Skoog, In search of the comfortable indoor environment: A comparison of the utility of objective and subjective indicators of indoor comfort, Building and Environment, 42, 1886-1890, (2007).

[4] Ashrae, Standard 62- 1989- Ventilation for Acceptable Indoor Air Quality, American Society of Heating, Refrigerating and Air-Conditioning Engineers, Atlanta, (1989).

[5] Ashrae, Standard 62- 2001- Ventilation for Acceptable Indoor Air Quality, American Society of Heating, Refrigerating and Air-Conditioning Engineers, Atlanta, (2001).

[6] Schramek, E., Recknagel-Sprenger Schramek- Isıtma ve Klima Tekniği EI Kitabı, TTMD, Ankara, (1999).

[7] Bas, E., Indoor Air Quality-A Guide for Facility Managers, The Fairmont Pres, Lilburn, Georgia, (2004).

[8] Karakoç, H., Kalorifer Tesisatı Hesabı, DemirDöküm Teknik yayınları, No:9, (2006).

[9] Theodosiou T.G. and Ordoumpozanis K.T., Energy, comfort and indoor air quality in nursery and elementary school buildings in the cold climatic zone of Greece. Energy and Building 40, 2207-2214, (2008).

[10] Ashrae, ASHRAE HandbookCD, 2001 Fundamentals, Chapter 8: Thermal Comfort, Atlanta,USA, (2003).

[11] Önen, E., Havalandırma ve Klima Tesisatı, Bayındırlık ve İskan bakanlığı, Teknik El kitabı No: 9, Başbakanlık Basımevi, Ankara, (1985).

[12] Orosa J.A. and Balina A. Passive climate control in Spanish Office buildings for long periods of time 43, 2005-2012 (2008).

[13] Shaharon M. N. and Jalaludin J., Thermal Comfort Assessment-A Study Toward Workers' Satisfaction in a Low Energy Office Building, American Journal of Applied Sciences 9 (7): 1037-1045, 2012.

[14] Deutsche Norm DIN EN 15251: 2012-12. Indoor environmental input parameters for design and assessment of energy performance of buildings addressing indoor air quality, thermal environment, lighting and acoustics. Berlin: Beuth Verlag GmbH.

[15] HKEPD (Hong Kong Environmental Protection Department). Guideline notes for the management of indoor air quality in offices and public places (draft). Indoor Air Quality Management Group, HKEPD (1999).

[16] Türkiye İstatistik Kurumu, http://www.tuik.gov.tr (Erişim Tarihi 08.06.2017). 
[17] Balıkesir Valiliği Sitesi, www.balikesir.gov.tr, (Erişim tarihi 2008).

[18] Balıkesir Meteoroloji Müdürlüğü - Günlük Klimatolojik Veriler, (Erişim tarihi 2008).

[19] Balıkesir Valiliği İl Halk Sağlığ1 Müdürlüğü “ $\mathrm{SO}_{2}$ ve $\mathrm{PM}$ 'ye ait günlük hava kirliliği değerleri, (Erişim tarihi 2008).

[20] Selici A.T.,' İç ortam Hava Kalitesini Etkileyen Kirletici ve Konfor Parametrelerinin Kaynakları ve Enerji Tüketimi Açısından İncelenmesi', Doktora Tezi, Fen Bilimleri Enstitüsü, Balıkesir Üniversitesi, Mart 2014. 